\title{
Affinity purification of 5-methylthioadenosine kinase and 5-methylthioribose/S-adenosylhomocysteine nucleosidase from Klebsiella pneumoniae
}

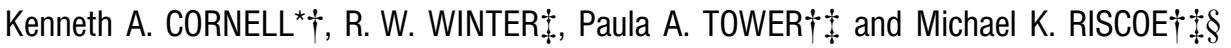 \\ *Department of Biochemistry and Molecular Biology, and †Division of Hematology and Oncology, Oregon Health Sciences University, 3181 SW Sam Jackson Park Rd., \\ Portland, OR 97201, U.S.A., and †.Department of Research Services, 151-0, Veterans Affairs Medical Center, 3710 SW U.S. Veterans Hospital Rd., Portland, OR 97201,
} U.S.A.

Two enzymes in the methionine salvage pathway, 5-methylthioribose kinase (MTR kinase) and 5'-methylthioadenosine/ $S$-adenosylhomocysteine nucleosidase (MTA/SAH nucleosidase) were purified from Klebsiella pneumoniae. Chromatography using a novel 5 -( $p$-aminophenyl)thioadenosine/5-( $p$ aminophenyl)thioribose affinity matrix allowed the binding and selective elution of each of the enzymes in pure form. The molecular mass, substrate kinetics and $\mathrm{N}$-terminal amino acid sequences were characterized for each of the enzymes. Purified MTR kinase exhibits an apparent molecular mass of 46-50 kDa by SDS/PAGE and S200HR chromatography, and has a $K_{\mathrm{m}}$ for
MTR of $12.2 \mu \mathrm{M}$. Homogeneous MTA/SAH nucleosidase displays a molecular mass of $26.5 \mathrm{kDa}$ by SDS/PAGE, and a $K_{\mathrm{m}}$ for MTA of $8.7 \mu \mathrm{M}$. Comparisons of the $\mathrm{N}$-terminal sequences obtained for each of the enzymes with protein-sequence databases failed to reveal any significant sequence similarities to known proteins. However, the amino acid sequence obtained for the nucleosidase did share a high degree of sequence similarity with the putative translation product of an open reading frame in Escherichia coli, thus providing a tentative identification of this gene as encoding an MTA/SAH nucleosidase.

\section{INTRODUCTION}

5-Methylthioribose (MTR) kinase is not present in mammalian cells but is essential for methionine recycling in plants, as well as in numerous bacterial and protozoan species (Scheme 1). Because of its prevalence in a number of bacterial and protozoan pathogens of humans, attention has turned to the enzyme as a target for the development of drugs to selectively exploit or subvert microbial methionine metabolism [1-3]. It has been demonstrated that MTR kinase-containing organisms are selectively killed by analogues of MTR [3-6]. Depending on their design, these analogues kill microbes by one or more of the following mechanisms: (1) direct inhibition of MTR kinase activity, thus preventing salvage of the energetically 'expensive' amino acid methionine; (2) conversion of the drug via MTR kinase and the salvage pathway into toxic derivatives of methionine or $S$-adenosylmethionine (SAM); and (3) conversion via MTR kinase to unstable intermediates which yield toxic products upon decomposition. One MTR analogue, 5-(trifluoromethyl)thioribose (TFMTR), acts as a subversive substrate of the methionine salvage pathway to yield an unstable intermediate which releases toxic carbonothioic difluoride [1]. More recently, Winter et al. [6] have described 5-( $p$-iodophenyl)thioribose (PIPTR) which is at least 10000 times more potent than TFMTR (e.g. $\mathrm{IC}_{50} \mathrm{~s}$ of $2.5 \mathrm{pM}$ and $40 \mathrm{nM}$ versus Klebsiella pneumoniae respectively). However, the precise mechanism by which this compound acts is not yet clear.

Further development of MTR analogues as selective antimicrobial agents would be greatly facilitated by the availability of pure target enzyme which could be used to screen new compounds. In addition, N-terminal sequence data from purified enzyme would provide valuable information required for cloning

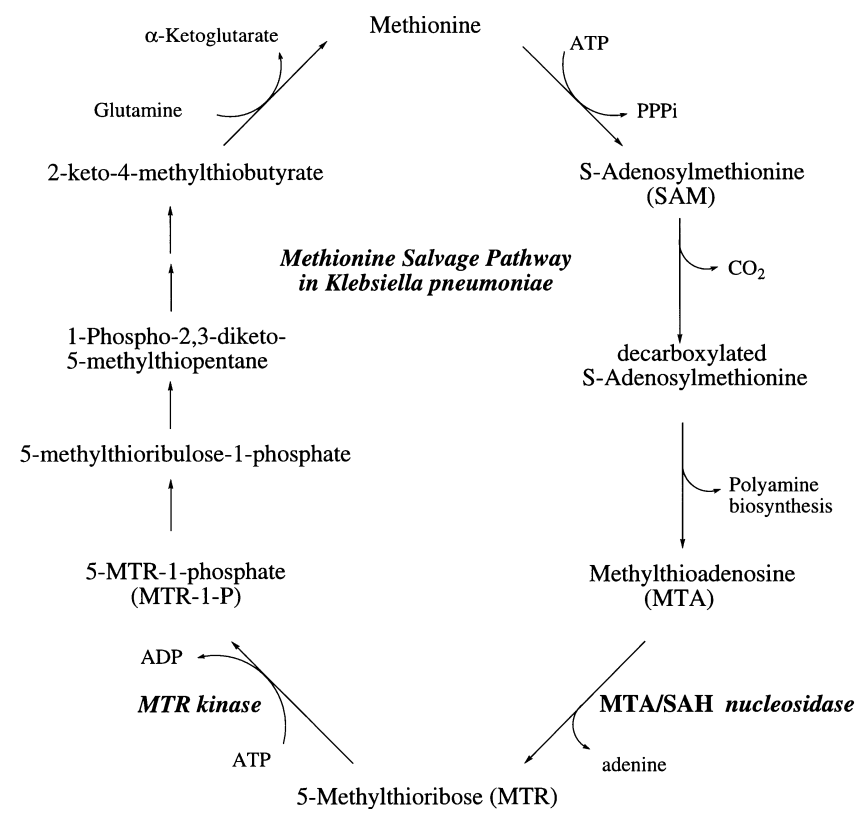

Scheme 1 The methionine salvage pathway via $5^{\prime}$-methylthioadenosine

Abbreviations used: CAPS, 3-(cyclohexylamino)propane-1-sulphonic acid; DTT, dithiothreitol; MTA, 5'-methylthioadenosine; MTR, 5-methylthioribose; PAPTA, 5'-(p-aminophenyl)thioadenosine; PAPTR, 5-(p-aminophenyl)thioribose; TFMTR, 5-(trifluoromethyl)thioribose; PIPTR, 5-( $p$-iodophenyl)thioribose; SAM, S-adenosyl-L-methionine; SAH, S-adenosylhomocysteine.

$\S$ To whom correspondence should be addressed. 
and expression of the corresponding gene. Because of its importance for future drug development efforts and for studies to investigate the regulation of MTR kinase expression, we set out to purify MTR kinase to homogeneity. Critical to the mission of obtaining pure material was the development of a novel substrateaffinity matrix, 5'-( $p$-aminophenyl)thioadenosine (PAPTA)/ 5-( $p$-aminophenyl)thioribose (PAPTR)-Sepharose. Herein we describe the use of this matrix to purify MTR kinase to homogeneity from a cell-free extract of $K$. pneumoniae, and the fortuitous co-purification of the enzyme $5^{\prime}$-methylthioadenosine (MTA) $/ S$-adenosylhomocysteine (SAH) nucleosidase.

\section{MATERIALS AND METHODS}

\section{Bacterial strains and culture conditions}

The clinical isolate of $K$. pneumoniae as well as the culture conditions used to maintain the organism for these studies have been described previously [4].

\section{Chemicals and substrates}

$S$-Adenosyl-L-[methyl $\left.-{ }^{14} \mathrm{C}\right]$ methionine $\left({ }^{14} \mathrm{C}-\mathrm{SAM} ; 100 \mu \mathrm{Ci} / \mathrm{ml}\right.$, $55 \mathrm{mCi} / \mathrm{mmol}$ ) was purchased from American Radiolabelled Chemicals (St. Louis, MO, U.S.A.). $\quad 5^{\prime}-\left[\right.$ methyl $\left.-{ }^{14} \mathrm{C}\right]-$ Methylthioadenosine $\left({ }^{14} \mathrm{C}\right.$-MTA $)$ was synthesized from ${ }^{14} \mathrm{C}$-SAM as described by Schlenk [7]. 5-[methyl- $\left.{ }^{14} \mathrm{C}\right]$ Methylthioribose $\left({ }^{14} \mathrm{C}\right.$-MTR) was produced from ${ }^{14} \mathrm{C}$-MTA by acid hydrolysis [8]. 5'-Tosyladenosine and 6-aminohexanoic acid $N$-hydroxysuccinimide ester-Sepharose 4B were obtained from Sigma Chemical Corp. (St. Louis, MO, U.S.A.). 4-Aminothiophenol was purchased from Aldrich (Milwaukee, WI, U.S.A.).

\section{Synthesis of PAPTA}

Solid sodium $(8.8 \mathrm{mmol})$ was dissolved in $100 \mathrm{ml}$ of reagentgrade methanol (Aldrich) with stirring in a round-bottomed flask. 4-Aminothiophenol (7.1 $\mathrm{mmol})$ was then dissolved into the mixture, followed by the addition of 5'-tosyladenosine (7.1 mmol). After flushing the vessel with nitrogen, it was tightly capped and allowed to stir for 2 days at room temperature. Conversion of the 5'-tosyladenosine to PAPTA was monitored by TLC on Whatman reverse-phase $\left(\mathrm{C}_{2}\right)$ plates using a solvent system composed of acetonitrile/water (15:1). To complete the purification, the mixture was evaporated to dryness and the residue extracted twice with a small volume of water. The remaining solid material (impure PAPTA) was recrystallized three times from methanol. The white crystalline product was greater than $99 \%$ pure as judged by TLC. The identity of the compound was confirmed by MS $(70 \mathrm{eV})$ and elemental analysis.

\section{Synthesis of PAPTA/PAPTR affinity matrix}

PAPTA-Sepharose was constructed by covalent linkage of the $p$-amino group of PAPTA to 6-aminohexanoic acid $N$-hydroxysuccinimide ester-Sepharose $4 \mathrm{~B}$ according to the manufacturer's protocol. Prior to coupling, $1 \mathrm{~g}$ of the dry resin was mixed overnight in $20 \mathrm{ml}$ of distilled water to yield approximately $3 \mathrm{ml}$ of hydrated matrix. The matrix was then rinsed on a scintered glass filter with $400 \mathrm{ml}$ of ice-cold $1 \mathrm{mM} \mathrm{HCl}$. PAPTA $(60 \mathrm{mg})$ was dissolved in $6 \mathrm{ml}$ of distilled water for $1 \mathrm{~h}$ in a boiling-water bath, followed by the addition of an equal volume of bicarbonate buffer $\left(0.2 \mathrm{M} \mathrm{NaHCO}_{3}, \mathrm{pH} 8.0 / 1 \mathrm{M} \mathrm{NaCl}\right)$ just before the addition of rinsed matrix. The ligand was allowed to react with the activated resin for $1 \mathrm{~h}$ at room temperature with constant agitation. Unbound ligand was removed from the resin by rinsing with $50 \mathrm{ml}$ of bicarbonate buffer. Unreacted sites were blocked by treatment with $15 \mathrm{ml}$ of $1 \mathrm{M}$ ethanolamine for $1 \mathrm{~h}$ at room temperature. Following this treatment, the matrix was rinsed extensively with five alternating washes $(100 \mathrm{ml}$ each $)$ of acetate buffer $(0.1 \mathrm{M}$ sodium acetate, $\mathrm{pH} 4 / 0.5 \mathrm{M} \mathrm{NaCl})$ and Tris buffer $(0.1 \mathrm{M}$ Tris, $\mathrm{pH} 8 / 0.5 \mathrm{M} \mathrm{NaCl})$. The PAPTASepharose was subsequently rinsed with S200 buffer [10 mM imidazole, $\mathrm{pH} 6.8 / 100 \mathrm{mM} \mathrm{NaCl} / 2 \mathrm{mM}$ dithiothreitol (DTT)/ $1 \%$ (v/v) glycerol] and stored at $4{ }^{\circ} \mathrm{C}$ until needed.

PAPTR-resin was synthesized by treating $2 \mathrm{ml}$ of PAPTASepharose with $5 \mathrm{ml}$ of pooled sample of partially purified K. pneumoniae MTA/SAH nucleosidase for $1 \mathrm{~h}$ at $37^{\circ} \mathrm{C}$ with constant agitation. After nucleosidase treatment, the resin was placed in a column $(1 \times 2 \mathrm{~cm})$ and washed extensively with S200 buffer. The PAPTR resin was stored at $4{ }^{\circ} \mathrm{C}$ in S200 buffer containing $0.2 \%$ azide.

\section{Enzyme assays and kinetics}

For enzyme purification purposes, MTR kinase activity was measured essentially as described by Gianotti et al. [4]. Briefly, enzyme samples $(1-10 \mu \mathrm{l})$ were incubated for $1 \mathrm{~h}$ at $37^{\circ} \mathrm{C}$ in $100 \mu \mathrm{l}$ of reaction mixture containing $100 \mathrm{mM}$ glycine ( $\mathrm{pH} 9.5$ ), $5 \mathrm{mM}$ ATP, $20 \mathrm{mM} \mathrm{MgCl}{ }_{2}, 5 \mathrm{mM}$ DTT and $5 \mu \mathrm{M}{ }^{14} \mathrm{C}-\mathrm{MTR}$ $(0.029 \mu \mathrm{Ci})$. The reaction was stopped by addition of $400 \mu \mathrm{l}$ of ice-cold ethanol and centrifuged ( $10000 \mathrm{~g}$ for $5 \mathrm{~min}$ ) to sediment precipitated material. A $450 \mu 1$ sample of the supernatant was

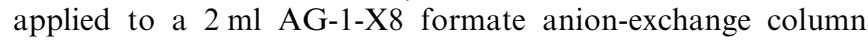
(Bio-Rad). Unreacted substrate was removed by rinsing the column $(3 \times 5 \mathrm{ml})$ with $0.01 \mathrm{M}$ sodium formate buffer $(\mathrm{pH} 5)$. Bound ${ }^{14} \mathrm{C}$-MTR-1-phosphate was eluted with $8 \mathrm{ml}$ of $0.75 \mathrm{M}$ sodium formate buffer ( $\mathrm{pH} \mathrm{5)}$. After thorough mixing, a $2 \mathrm{ml}$ sample of the eluate was added to $18 \mathrm{ml}$ of EcoLume scintillation cocktail (ICN) and the radioactivity quantified on a Beckman LS3801 liquid-scintillation counter. For enzyme kinetic studies, the assay was performed as described above, with ${ }^{14} \mathrm{C}-\mathrm{MTR}$ concentrations ranging from $0.5 \mu \mathrm{M}$ to $17.5 \mu \mathrm{M}$. Enzyme concentration and reaction duration were adjusted to limit conversion of substrate to less than $5 \%$. Results were plotted as double-reciprocal (Lineweaver-Burk) plots [9] and analysed for kinetic parameters using the Leonora enzyme kinetics program [10].

MTA nucleosidase activity was measured by following the conversion of ${ }^{14} \mathrm{C}$-MTA to ${ }^{14} \mathrm{C}$-MTR, essentially as described by Della-Ragione et al. [11] with minor modifications. The standard assay for following enzyme purification contained $25 \mu \mathrm{l}$ of sample, $190 \mathrm{mM}$ imidazole ( $\mathrm{pH} 7)$ and $37 \mu \mathrm{M}{ }^{14} \mathrm{C}$-MTA $(5 \mu \mathrm{Ci} /$ $\mu \mathrm{mol}$ ), in a total reaction volume of $200 \mu \mathrm{l}$. Reactions were incubated at $37^{\circ} \mathrm{C}$ for $60 \mathrm{~min}$ and stopped by addition of $50 \mu \mathrm{l}$ of ice-cold $3 \mathrm{M}$ trichloroacetic acid. Precipitated material was removed by centrifugation (10000 $\boldsymbol{g}$ for $10 \mathrm{~min}$ ). A $200 \mu \mathrm{l}$ sample of supernatant was applied to a $2 \mathrm{ml} \mathrm{AG50-X8} \mathrm{cation-exchange}$ column (Bio-Rad; 100-200 mesh, hydrogen-ion form), and unbound ${ }^{14} \mathrm{C}$-MTR eluted with $3 \mathrm{ml}$ of distilled water directly into a $20 \mathrm{ml}$ vial of scintillation cocktail. For kinetic analysis the substrate concentration ranged from $2.5 \mu \mathrm{M}$ to $20 \mu \mathrm{M}$. Enzyme concentration and reaction time were adjusted to limit substrate hydrolysis to less than $5 \%$.

\section{Preparation of enzyme extracts and initial chromatography}

Overnight cultures of $K$. pneumoniae grown at $37^{\circ} \mathrm{C}$ were diluted 100 -fold into 16 litres of methionine-free defined medium [12]. Cultures were incubated at $37^{\circ} \mathrm{C}$ with vigorous agitation until mid-log phase $\left(A_{545} \approx 0.6\right)$ and harvested by centrifugation 
( $5000 \mathrm{~g}$ for $15 \mathrm{~min}$ ). The resulting cell pellets (approx. $100 \mathrm{~g}$ wet weight) were stored at $-20{ }^{\circ} \mathrm{C}$ until needed. Unless otherwise stated, all subsequent steps in the enzyme purification scheme were carried out on ice or in a $4{ }^{\circ} \mathrm{C}$ refrigerated cold-room.

To prepare cell-free extracts, cell pellets were thawed and resuspended in $200 \mathrm{ml}$ of ice-cold ID buffer ( $10 \mathrm{mM}$ imidazole, pH 6.8/2 mM DTT). Cells were disrupted by four passages through a French Pressure cell (SLM-Aminco) at $1104 \times 10^{2} \mathrm{kPa}$ $\left(16000 \mathrm{lb} . / \mathrm{in}^{2}\right)$. Cell lysates were centrifuged at $4{ }^{\circ} \mathrm{C}(25000 \mathrm{~g}$ for $30 \mathrm{~min}$ ) to remove cellular debris. For an initial enrichment of MTR kinase activity, dry ammonium sulphate $(0.134 \mathrm{~g} / \mathrm{ml}$ lysate) was stirred into the cell lysate over the course of $2 \mathrm{~h}$. The lysate was stirred for an additional $1 \mathrm{~h}$, followed by centrifugation $(10000 \mathrm{~g}$ for $30 \mathrm{~min})$ to remove precipitated material. The supernatant (containing MTR kinase activity) was then dialysed extensively against ID buffer.

Before affinity chromatography, the dialysate was subjected to DEAE (anion exchange) and S200HR chromatography. Briefly, the dialysate $(400 \mathrm{ml})$ was loaded onto a DEAE-Sepharose $\mathrm{Cl}$ $6 \mathrm{~B}$ column $(25 \mathrm{~cm} \times 4 \mathrm{~cm})$ at a flow rate of $0.5 \mathrm{ml} / \mathrm{min}$. The column was washed with ID buffer ( 2 litres) until the $A_{280}$ of the eluent was below 0.05 . A linear gradient of $0-0.8 \mathrm{M} \mathrm{NaCl}$ in ID buffer (1.5 litre) was then applied to the column at a flow rate of $0.27 \mathrm{ml} / \mathrm{min}$. Fractions were collected every $15 \mathrm{~min}(\sim 4 \mathrm{ml} /$ fraction) and assayed for enzyme activity. Fractions containing high levels of MTR kinase activity were pooled and concentrated using Centriprep 10 ultrafiltration units (Amicon, Beverly, MA, U.S.A.) according to the manufacturer's specifications. The concentrated DEAE-purified MTR kinase pool was then rechromatographed on the DEAE column using a $0-0.5 \mathrm{M} \mathrm{NaCl}$ gradient. Fractions containing peak MTR kinase activity were pooled and concentrated as described above.

DEAE-purified MTR kinase (4 ml) was applied to a Sephacryl S200HR column $(80 \mathrm{~cm} \times 2.5 \mathrm{~cm})$ equilibrated in S200 buffer. The flow rate was adjusted to $4 \mathrm{ml} / \mathrm{h}$, with $15 \mathrm{~min}$ fractions collected and assayed for enzymic activity. An approximate molecular-mass elution profile was assigned by performing a parallel separation with a mixture of protein chromatographic standards (Pharmacia). Fractions containing peak levels of MTR kinase activity were pooled, concentrated by ultrafiltration, and stored at $4{ }^{\circ} \mathrm{C}$ for affinity chromatography.

\section{PAPTR affinity chromatography}

S200-purified MTR kinase $(2 \mathrm{ml})$ was recycled five times over a $3 \mathrm{ml}$ column of PAPTR-Sepharose. After the fifth application, the resin was washed with $20 \mathrm{ml}$ each of: (1) ID buffer + $100 \mathrm{mM} \mathrm{NaCl}$; (2) ID buffer $+500 \mathrm{mM} \mathrm{NaCl}$; and (3) ID buffer $+2 \mathrm{M} \mathrm{NaCl}$. MTR kinase activity was selectively removed by treatment with $20 \mathrm{ml}$ of $\mathrm{Mg} / \mathrm{ATP}$ buffer $(100 \mathrm{mM}$ glycine, $\mathrm{pH} 9.5 / 5 \mathrm{mM}$ ATP $/ 20 \mathrm{mM} \mathrm{MgCl}_{2}$ ) at $37^{\circ} \mathrm{C}$. The column was washed with an additional $20 \mathrm{ml}$ fraction of ID buffer $+100 \mathrm{mM}$ $\mathrm{NaCl}$, and finally with $18 \mathrm{ml}$ of a low-pH buffer $(100 \mathrm{mM}$ glycine, $\mathrm{pH} 2.5$ ) eluted directly into $2 \mathrm{ml}$ of $1 \mathrm{M}$ Tris ( $\mathrm{pH} 8.0$ ). All elutions were concentrated by Centriprep 10 ultrafiltration and assayed for enzymic activity as described above.

\section{Protein determination}

Protein concentrations were determined using a Coomassie ${ }^{\circledR}$ Plus kit (Pierce, Rockford, IL, U.S.A.) according to the manufacturer's specifications. Absorbances were monitored at $595 \mathrm{~nm}$ with BSA used as a protein standard.

\section{Protein analysis}

SDS/PAGE was performed using a $12.5 \%$-acrylamide resolving gel and 3\%-acrylamide stacking gel system [13] in a Hoefer Mighty Small II ${ }^{\circledR}$ apparatus. Electrophoresis was typically conducted for $1 \mathrm{~h}$ at $100 \mathrm{~V}$, followed by overnight staining of the gel in a solution of $0.05 \%$ Coomassie Blue dissolved in $50 \%$ methanol $/ 10 \%$ acetic acid. Resolved proteins were visualized following destaining in $50 \%$ methanol $/ 10 \%$ acetic acid.

For electroblotting, proteins were resolved by SDS/PAGE on $10 \%$-polyacrylamide gels and equilibrated briefly in 3-(cyclohexylamino)propane-1-sulphonic acid (CAPS) buffer (10 mM CAPS $/ 10 \%$ methanol, pH 11) [14]. Proteins were then transferred to poly(vinylidene difluoride) membranes at $50 \mathrm{~V}$ for 35 min, using the CAPS buffer system, in a water-cooled Hoefer TE series TransPhor electrophoresis chamber. Proteins were visualized by brief $(1 \mathrm{~min})$ staining of the poly(vinylidene difluoride) membrane with Coomassie Blue $(0.1 \%$ in $50 \%$ methanol), destaining with $50 \%$ methanol $/ 10 \%$ acetic acid, followed by extensive rinsing in distilled water. Stained protein bands were excised and submitted to the Portland VAMC Core Molecular Biology facility for N-terminal sequencing on an Applied Biosystems automated peptide sequencer.

\section{RESULTS}

\section{Initial purification of MTR kinase}

MTR kinase was initially purified from cell-free lysates of $K$. pneumoniae using a succession of DEAE and S200HR chromatographic steps. Upon completion of size-exclusion chromatography, the enzyme had been purified approx. 1500-fold with an overall yield of $55 \%$ (Table 1). An estimated molecular mass for MTR kinase of $50 \mathrm{kDa}$ was obtained from S200HR chromatography by comparing the elution of MTR kinase activity with the elution profile of proteins of established molecular mass.

Table 1 Purification of MTR kinase from $K$. pneumoniae

\begin{tabular}{|c|c|c|c|c|}
\hline Purification step & $\begin{array}{l}\text { Specific activity } \\
\text { (pmol/min per mg } \\
\text { of protein) }\end{array}$ & $\begin{array}{l}\text { Total protein } \\
(\mathrm{mg})\end{array}$ & $\begin{array}{l}\text { Yield } \\
(\%)\end{array}$ & Fold purification \\
\hline Crude & 7.93 & 1571 & 100 & 1 \\
\hline$\left(\mathrm{NH}_{4}\right)_{2} \mathrm{SO}_{4}(25 \%$ fraction-supernatant) & 440.2 & 125 & 451 & 55 \\
\hline DEAE-Sepharose (0-0.8 M NaCl gradient) & 1746.3 & 4.92 & 70 & 220 \\
\hline DEAE-Sepharose (0-0.5 M NaCl gradient) & 5283.5 & 1.34 & 58 & 666 \\
\hline S2OOHR & 11634.5 & 0.58 & 55 & 1467 \\
\hline 'PAPTR' affinity chromatography & 85200 & 0.015 & 11 & 10744 \\
\hline
\end{tabular}




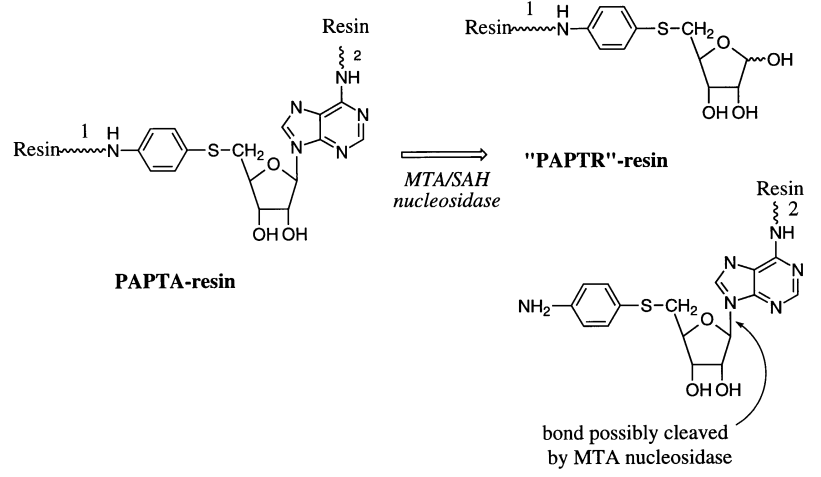

Scheme 2 Schematic diagram depicting the two possible linkages of PAPTA to Sepharose CH-4B and the synthesis of PAPTR affinity matrix

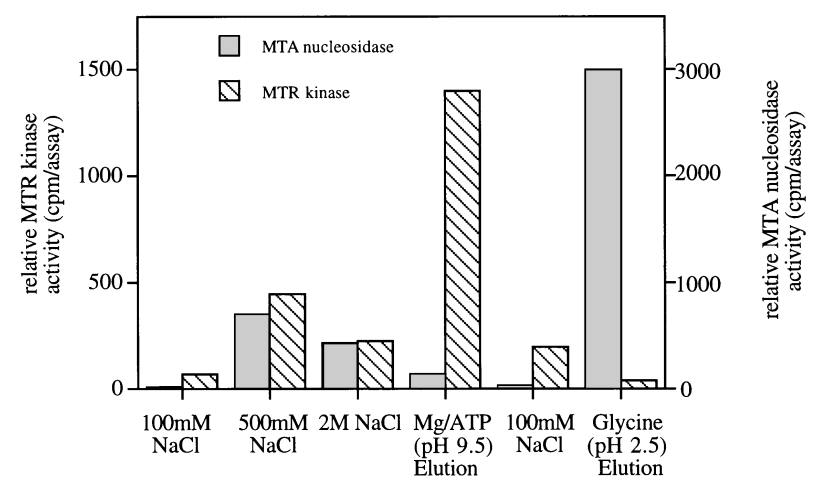

Figure 1 Elution of MTR kinase and MTA nucleosidase activity from PAPTA/PAPTR affinity matrix

\section{PAPTA/PAPTR affinity chromatography}

Chromatography of MTR kinase on the affinity matrix (Scheme 2) improved the purification factor to nearly 11000 -fold with an $11 \%$ overall yield (Table 1). As demonstrated in Figure 1, most of the MTR kinase activity remained on the affinity matrix even after treatment with $2 \mathrm{M} \mathrm{NaCl}$, and was selectively eluted from the column when treated under conditions which are known to be optimal for activity of the Klebsiella enzyme ('Mg/ATP' elution: $100 \mathrm{mM}$ glycine buffer, $\mathrm{pH} 9.5 / 5 \mathrm{mM}$ ATP $/ 20 \mathrm{mM}$ $\mathrm{MgCl}_{2} / 5 \mathrm{mM}$ DTT). Presumably, these conditions favour phosphorylation of the bound affinity ligand and subsequent release of MTR kinase. A final elution of the column with $100 \mathrm{mM}$ glycine $(\mathrm{pH} 2.5)$ to elute remaining proteins from the matrix failed to yield any significant MTR kinase activity. However, subsequent analysis indicated that this fraction contained abundant MTA/SAH nucleosidase activity (Figure 1).

\section{Enzyme analysis}

SDS/PAGE analysis of fractions from the affinity resin revealed a single protein band with a molecular mass of $\sim 46 \mathrm{kDa}$ in the ' $\mathrm{Mg}$ /ATP' elution (Figure 2, panel [A], lane B). This value is consistent with the molecular mass predictions obtained by S200HR chromatography. SDS/PAGE analysis of the final $100 \mathrm{mM}$ glycine eluate (the fraction containing the highest MTA/SAH nucleosidase activity) revealed a single protein band with a relative molecular mass of $26.5 \mathrm{kDa}$ (Figure 2, panel [B], lane D).
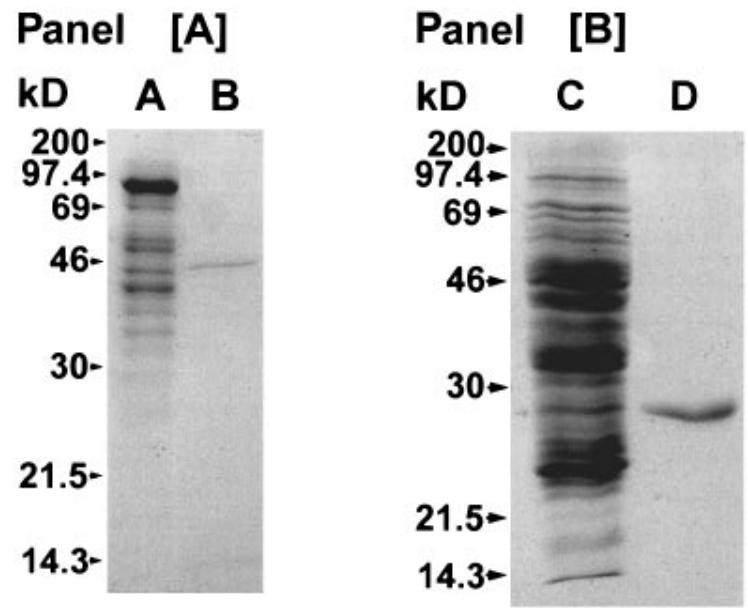

Figure 2 SDS/PAGE analysis of affinity-purified MTR kinase and MTA nucleosidase

Panel $[\mathbf{A}]$ : lane A, S200HR pool containing MTR kinase activity applied to the affinity resin; lane B, 'Mg/ATP, pH 9.5' elution containing purified MTR kinase. Panel [B]: lane C, S200HR pool containing MTA/SAH nucleosidase activity; lane D, 'glycine, pH 2.5' elution containing purified MTA/SAH nucleosidase. KD, kDa.

Kinetic analysis of homogeneously purified MTR kinase revealed a $K_{\mathrm{m}}$ for MTR of $12.2 \mu \mathrm{M}$ (Figure 3a). For purified MTA/SAH nucleosidase, a $K_{\mathrm{m}}$ for MTA of $8.7 \mu \mathrm{M}$ was determined (Figure $3 \mathrm{~b}$ ). Both $K_{\mathrm{m}}$ values were extracted from double-reciprocal plots using the Leonora enzyme kinetics program. N-terminal sequencing of both affinity-purified enzymes allowed the identification of 19 of the first 20 amino acid residues for the MTR kinase, and 35 residues for MTA/SAH nucleosidase (Figure 4).

\section{DISCUSSION}

Methionine serves as a structural component of proteins as well as providing the initiator amino acid during protein synthesis [15]. Upon activation to SAM, it serves as a source of methyl groups for a variety of transmethylation reactions, and as the source of propyl amine groups for polyamine biosynthesis [16]. To meet the high demand for this amino acid, micro-organisms obtain methionine by de novo synthesis and through a variety of salvage routes. Many organisms are able to salvage methionine from MTA, thereby conserving the amino acid consumed during polyamine synthesis.

The salvage of methionine from MTA has been most extensively characterized in the gram negative bacterium, $K$. pneumoniae $[17,18]$. The present paper describes the purification to homogeneity of the first two enzymes involved in this cycle: MTA/SAH nucleosidase and MTR kinase. At first glance, MTR kinase appears to be an ideal target for anti-microbial chemotherapeutic drug development, since it has no corresponding human equivalent and recognizes a substrate that is not present in mammalian cells. Previously, it has been shown in a number of biological systems that the presence of MTR kinase can be selectively exploited by subversive substrates which are metabolized by the enzyme to toxic methionine analogues or to liberate highly reactive intermediates $[1,19,20]$.

Because of the dual role of microbial MTA/SAH nucleosidase in regulating intracellular levels of both MTA and SAH, it also represents an attractive target for drug development. Elevated 

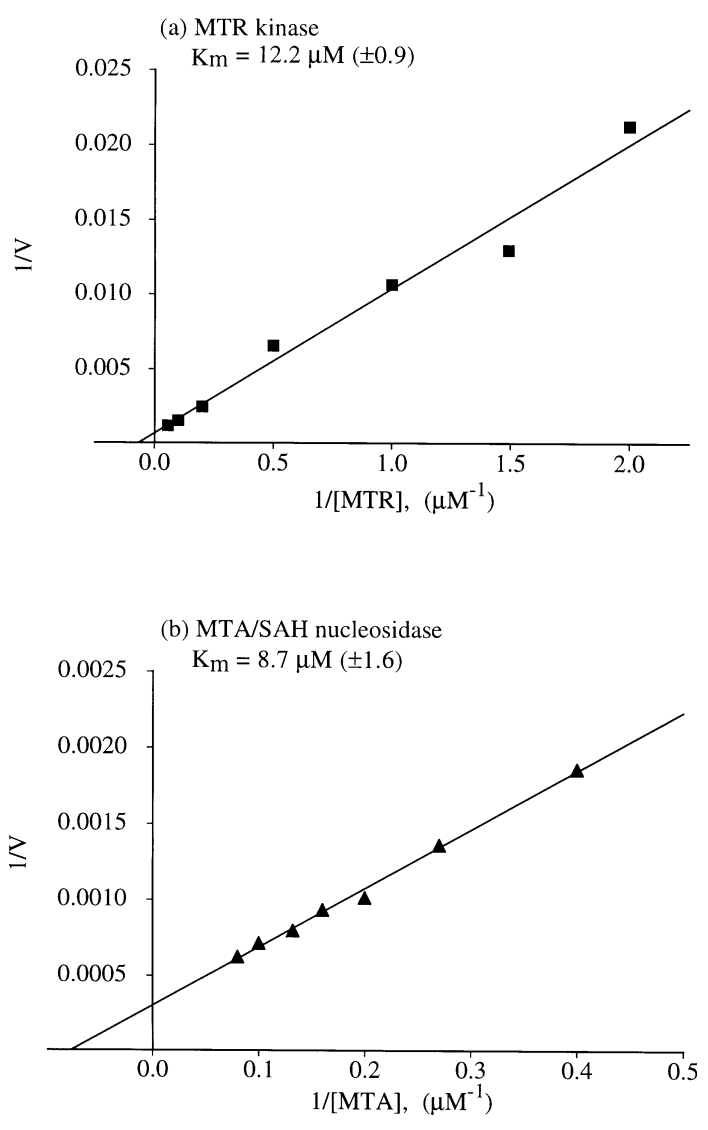

Figure 3 Lineweaver-Burk plots of (a) MTR kinase and (b) MTA/SAH nucleosidase activity as a function of substrate concentration

Each point is the mean value of at least four experimental determinations. In the case of MTR kinase, the concentration of ATP was fixed at $5 \mathrm{mM}$.

levels of SAH and MTA inhibit methylation reactions [21-24] and polyamine synthesis [25-27]. Nucleoside analogues which selectively inhibit the nucleosidase could act to kill invading micro-organisms by perturbing methylation processes and polyamine levels.

The primary goal of our study was to purify MTR kinase. Affinity chromatography on PAPTR-Sepharose represented the key step in the purification of this enzyme to homogeneity. The choice of this particular affinity matrix was based on the remarkable affinity of the enzyme for various arylthio-substituted derivatives [6]. The resin was prepared by linking PAPTA to cyanogen bromide-activated Sepharose $4 \mathrm{~B}$, presumably yielding a mixed matrix in which the ligand is bound through the $p$-amino group of the phenyl side-chain or the 6-position amine of the adenine ring (or possibly both). The glycosidic bond was cleaved by the application of a partially purified preparation of $K$. pneumoniae MTA/SAH nucleosidase to yield the final PAPTR matrix. Purification of MTR kinase was achieved by applying selective assay-like elution conditions, i.e. $\mathrm{pH} 9.5$ in the presence of ATP. We believe that under these conditions, MTR kinase is eluted as the bound PAPTR ligand becomes phosphorylated. Despite rather harsh washing conditions, MTA/SAH nucleosidase applied to the column to generate the PAPTR ligand remained bound to the matrix until it was eluted with an acidic $\mathrm{pH}$ buffer (100 mM glycine, $\mathrm{pH} 2.5$ ). Possibly, this strong retention of the nucleosidase to the matrix is caused by the presence of non-hydrolysable ligand, due to the alternative linkage of the PAPTA via the 6-position amine of the adenine ring.

MTR kinase activity has been detected in a variety of bacteria, protozoa and plants [1,3,28-32]. The enzyme has been partially purified from Enterobacter aerogenes [29], K. pneumoniae [4] and seeds of Lupinus luteus [28]. Several investigators estimated the molecular mass of native MTR kinase to be in the range of $70 \mathrm{kDa}$, based on gel-filtration analysis [4,28]. Our own gelfiltration studies and SDS/PAGE analysis indicate a monomer size nearer to $50 \mathrm{kDa}$. However, it should be noted that the elution profile of activity from the S200HR column is quite broad, thus we cannot accurately assess the subunit make-up of the native enzyme. The substrate affinity displayed by the purified kinase $\left(K_{\mathrm{m}}\right.$ for MTR of $\left.12.2 \mu \mathrm{M}\right)$ is similar to the Michaelis constants determined by other investigators for partially purified enzymes $[4,28,33]$.

MTA/SAH nucleosidase has previously been purified to homogeneity from $E$. coli using an $S$-formycinyl homocysteine-Sepharose affinity column [11]. Della-Ragione et al. [11] have characterized this enzyme extensively and report that it functions as a monomer with a native molecular mass of $26.5 \mathrm{kDa}$. These observations are consistent with the results we obtained from SDS/PAGE analysis of homogeneously purified $K$. pneumoniae nucleosidase. However, our results indicate that the Klebsiella enzyme $\left(K_{\mathrm{m}}\right.$ for $\left.\mathrm{MTA}=8.7 \mu \mathrm{M}\right)$ is markedly different from MTA/SAH nucleosidase derived from $E$. coli and L. luteus, which exhibit much higher affinities for MTA $\left(K_{\mathrm{m}}=\right.$ $0.4 \mu \mathrm{M}$ for both) [11,34]. It is noteworthy that unlike $K$. pneumoniae, E. coli is incapable of methionine salvage from MTA since it lacks MTR kinase (M. K. Riscoe unpublished observations). Instead, it has been reported that MTR produced in $E$. coli by the enzymic cleavage of MTA is exported [35,36]. Therefore, the observed differences in substrate affinities displayed by MTA/SAH nucleosidases may be a reflection of the metabolism of MTA and disposition of its products, i.e. export versus salvage of MTR.

In conclusion, this study highlights a method for purifying MTR kinase and MTA/SAH nucleosidase to homogeneity from the pathogen $K$. pneumoniae. Sufficient material was obtained to allow the determination of the $\mathrm{N}$-terminal amino acid sequence of each of the enzymes. Comparing the 19 amino acid sequence found for MTR kinase to sequences contained in

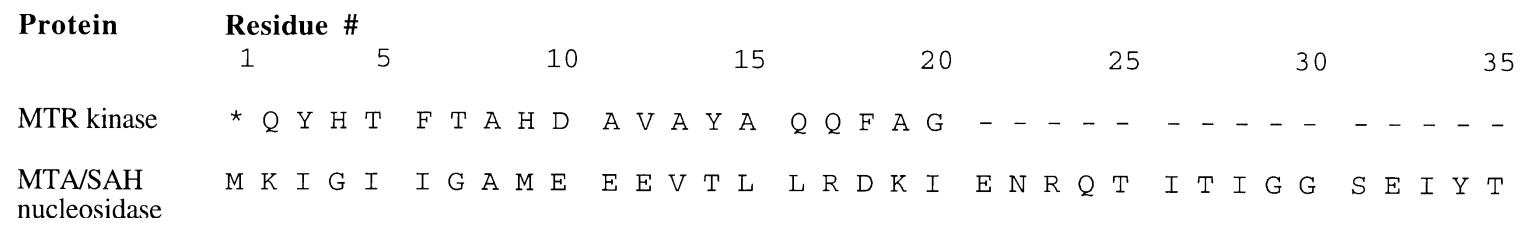

Figure $4 \quad \mathrm{~N}$-terminal amino acid sequences of affinity purified MTR kinase and MTA/SAH nucleosidase 
SwissProt and PIR data banks failed to reveal any significant sequence similarities to other proteins or putative translation products. However, analysis of the SwissProt database revealed a $95 \%$ identity between the Klebsiella MTA/SAH nucleosidase $\mathrm{N}$-terminal residues and a putative translation product of the $p f s$ gene (accession no. P24247) reported upstream of the $d g t$ gene in E. coli [37]. Based on the presence of conserved sequence motifs shared with known nucleoside phosphorylases, investigators have predicted that the $p f s$ gene product (calculated molecular mass $\approx 24 \mathrm{kDa}$ ) is a nucleosidase of unknown specificity [38]. Investigations into the identification of this region as encoding the MTA/SAH nucleosidase are currently under way in our laboratory.

Finally, it is hoped that the information presented in this article will facilitate the ultimate goal of cloning and sequencing the genes encoding MTR kinase and MTA/SAH nucleosidase. Subsequent over-expression of the genes would provide large quantities of both enzymes suitable for ongoing rational drug design and drug screening efforts.

The authors thank Ms. Linda L. Johnson for technical assistance in the preparation of cell cultures. In addition, we thank Drs. Thomas Allen and Daniel Carr, and Darrick Carter for assistance in computer database analysis. We gratefully acknowledge support from the Veterans Affairs Medical Research Program. This project was also supported in part through financial contributions of the Collins Medical Trust of Oregon, the Medical Research Foundation of Oregon, and Interlab Inc. (Lake Oswego, OR, U.S.A.). K. A.C. receives support from the National Institutes of Health Molecular Hematology Training Program Grant \#T32-HL07781 awarded to the Oregon Health Sciences University, and is the recipient of an N. L. Tartar Trust Fellowship and a Portland V.A. Medical Center Research Fellowship.

\section{REFERENCES}

1 Riscoe, M. K., Tower, P., Peyton, D., Ferro, A. Fitchen, J. H. (1991) in Biochemical Protozoology (Coombs, G. and North, M., eds.), pp. 450-457, Taylor and Francis, London

2 Riscoe, M. K., Ferro, A. and Fitchen, J. H. (1989) Parasitol. Today 5, 330-333

3 Riscoe, M. K., Ferro, A. J. and Fitchen, J. H. (1988) Antimicrob. Agents Chemother. 32, 1904-1906

4 Gianotti, A. J., Tower, P. A., Sheley, J. H., Conte, P. A., Spiro, C., Ferro, A. J. Fitchen, J. H. and Riscoe, M. K. (1990) J. Biol. Chem. 265, 831-837

5 Tower, P., Johnson, L., Ferro, A., Fitchen, J. and Riscoe, M. K. (1991) Antimicrob. Agents Chemother. 35, 1557-1561

6 Winter, R., Cornell, K., Johnson, L. and Riscoe, M. (1993) Bioorg. Med. Chem. Lett. 3, 2079-2082
7 Schlenk, F. (1983) Adv. Enzymol. 54, 195-265

8 Borchardt, R. T., Huber, J. A. and Wu, Y. S. (1976) J. Org. Chem. 41, 565-567

9 Lineweaver, H., Burk, D. and Deming, W. E. (1934) J. Am. Chem. Soc. 56, 225-230

10 Cornish-Bowden, A. (1995) Analysis of Enzyme Kinetic Data, Oxford University Press, Oxford

11 Della-Ragione, F., Porcelli, M., Carteni-Farina, M., Zappia, V. and Pegg, A. E. (1985) Biochem. J. 232, 335-341

12 Tower, P., Alexander, D., Johnson, L. and Riscoe, M. K. (1993) J. Gen. Microbiol 139, 1027-1031

13 Laemmli, U. K. (1970) Nature (London) 227, 680-685

14 LeGendre, N., Mansfield, M, Weiss, A. and Matsudaira, P. (1993) in A Practical Guide to Protein and Peptide Purification for Microsequencing (Matsudaira, P., ed.), pp. 71-101, Academic Press, San Diego

15 Cooper, A. J. L. (1983) Annu. Rev. Biochem. 53, 187-222

16 Tabor, H., Tabor, C. and Rosenthal, S. (1961) Annu. Rev. Biochem. 30, 579-604

17 Myers, R. W., Wray, J. W., Fish, S. and Abeles, R. H. (1993) J. Biol. Chem. 268 24785-24791

18 Myers, R. and Abeles, R. (1990) J. Biol. Chem. 265, 16913-16921

19 Fitchen, J. H., Riscoe, M. K. and Ferro, A. J. (1988) Adv. Exp. Med. Biol. 250, 199-210

20 Riscoe, M. K., Fitchen, J. and Ferro, A. (1989) U. S. Patent 823,929

21 Pugh, C. S. G., Borchardt, R. T. and Stone, H. 0. (1977) Biochemistry 16, 3928

22 Borchardt, R. T. (1980) J. Med. Chem. 23, 347-357

23 Galletti, P., Manna, C., Oliva, A., Giordano, F., Della, R. F. and Carteni-Farina, M. (1981) Boll. Soc. Ital. Biol. Sper. 57, 1188-1194

24 Galletti, P., Oliva, A., Manna, C., Della-Ragione, F. and Carteni-Farina, M. (1981) FEBS Lett. 126, 236-240

25 Pajula, R. L. and Raina, A. (1979) FEBS Lett. 99, 343-345

26 Tang, K.-C., Pegg, A. E. and Coward, J. K. (1980) Biochem. Biophys. Res. Commun. 96, 1371-1377

27 Coward, J. K., Motola, N. C. and Moyer, J. D. (1977) J. Med. Chem. 20, 500-505

28 Guranowski, A. (1983) Plant Physiol. 71, 932-935

29 Ferro, A. J. and Marchitto, K. S. (1983) Methods Enzymol. 94, 361-364

30 Kushad, M. M., Richardson, D. G. and Ferro, A. J. (1982) Biochem. Biophys. Res. Commun. 108, 167-173

31 Kushad, M. M., Richardson, D. G. and Ferro, A. J. (1985) Plant Physiol. 79, 525-529

32 Yung, K. H., Yang, S. F. and Schlenk, F. (1982) Biochem. Biophys. Res. Commun. 104, 771-777

33 Ferro, A. J., Barrett, A. and Shapiro, S. K. (1978) J. Biol. Chem. 253, 6021-6025

34 Guranowski, A. B., Chiang, P. K. and Cantoni, G. L. (1981) Eur. J. Biochem. 114, 293-299

35 Schroeder, H. R., Barnes, C. J., Bohinski, R. C., Mumma, R. 0. and Mallette, M. F. (1972) Biochim. Biophys. Acta 273, 254-264

36 Schroeder, H. R., Barnes, C. J., Bohinski, R. C. and Mallette, M. F. (1973) Can. J. Microbiol. 19, 1347-1354

37 Wurgler, S. and Richardson, C. C. (1990) Proc. Natl. Acad. Sci. U.S.A. 87 2740-2744

38 Mushegian, A. R. and Koonan, E. V. (1994) Protein Sci. 3, 1081-1088

Received 4 December 1995/22 February 1996; accepted 11 April 1996 